\title{
Prevention of Ebola
}

\author{
Pouya Metanat ${ }^{1, *}$ \\ ${ }^{1}$ University of Nebraska, Omaha, USA \\ *Corresponding author: Pouya Metanat, University of Nebraska, Omaha, USA. Tel:+1-4027537316, E-mail: pmetanat@unomaha.edu
}

Received: January 14, 2015; Accepted: January 21, 2015

\section{Dear Editor,}

I have read Keshtkar Jahromi's paper, "Ebola Hemorrhagic Fever" (1), which was an informative review on Ebola. However, despite many efforts in this area, there is no specific treatment or effective FDA-approved vaccine against Ebola virus. So far, The primary preventive measures that are known including understanding of clinical presentation, prompt diagnosis, patients isolation, and implementing adequate sterilization procedures (1-5). Furthermore, we should Identify high risk individuals to prevent further spread of infection among high risk population. According to Center for Disease Control and Prevention (CDC), the people at high risk are as follows (2):

1- Those who have contacted with objects contaminated with infected body fluids such as needle, syringes, etc.,

2- Those who have exposed with infected fluids via eye, nose, and mouth, or directly on through their skin,

3-The people who are in close contact with a patient in a healthcare facility, his/ her household items, or involved in direct patient care in any healthcare settings,

4- The people who have travelled on an airplane with a sick person,

5- Those who have a travel history to a country with a large Ebola outbreak within the past 21 days.

Moreover, the primary preventive measures are identified as Following $(1,2)$ :

1- Hand hygiene or using an alcohol-based sanitizer,

2- Avoiding contact with the blood and body fluids of patients Infected with Ebola,

3- Avoiding contact with the body of people died from Ebola hemorrhagic fever,

4- To avoid touching bats and nonhuman primates,
5- Promptly reporting any potential unprotected Ebola exposure or illness,

6-Getting medical care immediately, if someone has developed fever, headache, muscle pain, stomach pain, diarrhea, vomiting, fatigue, or unexplained bleeding,

7- Limiting contact with other people when a person is sick.

Recovery from Ebola disease depends on suitable supportive care and also patient's immune level. Experimental vaccines and drugs for Ebola are under development, and are not FDA- approved yet (1-5). People recovering from Ebola infection develop antibodies for at least 10 years. However, it is not known whether these people are immune for life, or if they are vulnerable to different species of Ebola. Therefore, control of infection is a key strategy in preventing spread of Ebola virus (2-4).

\section{References}

1. Keshtkar Jahromi N, Sharifi-Mood B. Ebola Hemorrhagic Fever. Int J Infect. 2015;2(1):e22401.

2. Centers for Disease Control and Prevention.. Centers for Disease Control and Prevention.Review of Human-to-Human Transmission of Ebola Virus. 2014. Available from: http:/|www.cdc.gov/vhf/ebola/ transmission/human-transmission.html.

3. Abutaleb Y. U.S. . FDA Issues Emergency Authorization for Two New Ebola Tests.Medscape. 2014. Available from: http://www.medscape. com/viewarticle/833986.

4. Wilson J. In Ebola fight, security forces to make villagers comply with medical plan. 2014. Available from: http://edition.cnn. com/2014/07/30/health/ebola-american-aid-workers/index. html?hpt=hp_t1.

5. Smith LM, Hensley LE, Geisbert TW, Johnson J, Stossel A, Honko $\mathrm{A}$, et al. Interferon-beta therapy prolongs survival in rhesus macaque models of Ebola and Marburg hemorrhagic fever. J Infect Dis. 2013;208(2):310-8. 